\title{
20. FACTORS INFLUENCING THE RARE EARTH ELEMENT COMPOSITION OF HYDROTHERMAL PRECIPITATES, EAST PACIFIC RISE ${ }^{1}$
}

\author{
Douglas E. Ruhlin and Robert M. Owen, Department of Atmospheric and Oceanic Science, \\ The University of Michigan ${ }^{2}$
}

\begin{abstract}
Site 598 sediments were analyzed to determine the factors controlling the rare earth element (REE) geochemistry of the hydrothermal component. Site 598 provides an ideal sample suite for this purpose. Samples are lithologically "simple," primarily consisting of a hydrothermal component and biogenous carbonates. Also, the composition of the hydrothermal component appears unchanged through time or space, and the site appears to have undergone minimal diagenetic alteration. The shale-normalized REE patterns are similar to the pattern of seawater, varying only in absolute REE content. The REE content increases with distance from the paleorise crest and exhibits a pronounced increase in sediments deposited below the paleolysocline. Results presented are consistent with the following model: the source mechanism for the REE content of hydrothermal sediments is scavenging by Fe oxyhydroxides from seawater. With prolonged exposure to seawater resulting from transport far from the injection point and/or long residence at the seawatersediment interface, the absolute REE content of hydrothermal sediments increases and becomes more like seawater.
\end{abstract}

\section{INTRODUCTION}

Investigations of hydrothermal precipitates from various locations (e.g., Edmond, Corliss, et al., 1979; Edmond, Measures, et al., 1979), laboratory experimental studies (e.g., Mottl and Seyfried, 1980), and the results of quantitative simulation models (e.g., Bowers and Taylor, 1983) all have established that hydrothermal precipitates can and often do exhibit a broad range of chemical compositions. For any given element, this compositional variability may arise from (1) differences in the primary composition of the hydrothermal fluid; (2) variations in key parameters such as temperature, permeability, and water-rock ratio during seawater-basalt interaction; (3) the degree of subsurface mixing between seawater and the hydrothermal fluid; and (4) chemical reactions between precipitates in the debouched fluid and ambient bottom waters. Within this context, the general objective of this study was to determine the factors that influence the rare earth element (REE) content of hydrothermal deposits. Specifically, we have investigated the REE geochemistry of hydrothermal sediments recovered from DSDP Site $598\left(19^{\circ} 00.283^{\prime} \mathrm{S}, 124^{\circ} 40.606^{\prime} \mathrm{W}\right)$ during Leg 92, which represent a complete record of hydrothermal sedimentation at the East Pacific Rise over the past 16 m.y.

Hydrothermal sediments from the Bauer Deep and from the East Pacific Rise and basal metalliferous sediments from DSDP sites all have REE patterns strongly resembling seawater patterns (Bender et al., 1971; Dymond et al., 1973). Although REE depletion and a REE abundance pattern similar to that of seawater are considered characteristic of newly formed hydrothermal pre-

\footnotetext{
${ }^{1}$ Leinen, M., Rea, D. K., et al., Init. Repts. DSDP, 92: Washington (U.S. Govt. Printing Office).

2 Address: Department of Atmospheric and Oceanic Science, The University of Michigan, Ann Arbor, MI 48109.
}

cipitates (Toth, 1980), there is evidence that materials that have been carried far away from active vents will have higher REE levels and will be particularly enriched in Ce, possibly because of REE scavenging by the particulates. Dymond et al. (1973) observed that the Ce/ $\mathrm{Sm}$ ratio in hydrothermal sediments is negatively correlated with $\mathrm{Fe}$ and seems to increase in metalliferous sediments away from the rise crest. They also note, however, that the total REE enrichment observed in their samples could have been due to small amounts of phosphatic fish debris present in all samples. Lyle (1981) found that ferromanganese coatings from the rise crest have lower absolute REE abundances and an REE pattern more similar to that of seawater than coatings from areas not on the rise crest. Samples from areas not on the rise crest in Lyle's (1981) study were also much more highly enriched in $\mathrm{Ce}$, as are ferromanganese nodules. Considerable caution must be exercised in making any analogy between ferromanganese coatings, which are presumably derived from a hydrogenous source, and the metalliferous sediments resulting from hydrothermal sources. Although these deposits may have similar mineralogies, their compositional differences are quite pronounced (Cronan, 1980).

In summary, the limited sediment composition data presently available do not permit a definitive interpretation of these results, but they do strongly suggest a testable hypothesis: the primary mechanism responsible for the acquisition of REEs by hydrothermal precipitates involves the scavenging of these elements from seawater. Investigations of REE profiles in seawater also support this hypothesis. For example, Klinkhammer et al. (1983) have observed significant differences in the concentration versus depth profiles of REEs in seawater near hydrothermal vents compared to profiles obtained from stations not influenced by hydrothermal plumes. These authors suggest a number of possible processes that could account for these differences, but they emphasize that 
the most plausible mechanism is one that involves scavenging of REE by hydrothermal precipitates. Such a process would be consistent with previous observations that $\mathrm{Mn}$ and, particularly, Fe oxyhydroxides exhibit a high affinity for scavenging REEs in both marine and lacustrine waters (e.g., Goldberg, 1963; Piper, 1974a,b; Owen and Mackin, 1980).

As discussed below, the sediments collected during Leg 92 are lithologically "simple," that is, they primarily consist only of biogenous carbonates and hydrothermal precipitates, and apparently have experienced little or no diagenetic alteration. Consequently, these sediments are particularly well suited for use in an unambiguous test of the hypothesis stated above. In the present study we have attempted to verify or reject this hypothesis on the basis of observed relationships between (1) the concentration and mass accumulation rates (MARs) of $\mathrm{Fe}$ and the REEs in the hydrothermal sediments, and (2) systematic variations in the REE abundances and patterns of hydrothermal sediments versus certain proxy indicators of the exposure of these precipitates to seawater.

\section{ANALYTICAL PROCEDURES}

In total, 50 samples from Hole 598 were analyzed for $\mathrm{Mn}, \mathrm{Fe}, \mathrm{La}$, $\mathrm{Ce}, \mathrm{Nd}, \mathrm{Sm}, \mathrm{Eu}, \mathrm{Tb}, \mathrm{Yb}$, and $\mathrm{Lu}$ (and several other elements not discussed here) by instrumental neutron activation analysis (INAA) at the Phoenix Memorial Laboratory, The University of Michigan, using standard INAA procedures (Gordon et al., 1968; Dams and Robbins, 1970). A preliminary test showed that the presence of a small amount of sea salt (as freeze-dried residue) would not interfere with our results; consequently, sample preparation did not require successive washing and drying cycles. After freeze drying, each sample was split into two portions. For elements with relatively short half-lives (e.g., Mn), the procedure involved sealing about $50 \mathrm{mg}$ of sample in a polyethylene microvial, irradiating the sample for $20 \mathrm{~s}$ at a neutron flux of about $5 \times 10^{12} \mathrm{n} / \mathrm{cm}^{2} / \mathrm{s}$ (Cd ratio approximately 10$)$, and counting for $100 \mathrm{~s}$ using a pair of multiplexed Ge-Li detectors after a cooling period of $12 \mathrm{~min}$. For elements with relatively long half-lives, approximately $200 \mathrm{mg}$ of sample were sealed in quartz tubing, irradiated for $12 \mathrm{hr}$. at a neutron flux of $2 \times 10^{13} \mathrm{n} / \mathrm{cm}^{2} / \mathrm{s}$ (Cd ratio approximately 3 ), and counted for $1 \mathrm{hr}$. after a cooling period of 1 week (for La, Sm, and $\mathrm{Lu}$ ) or 4 weeks (for all other elements).

Each batch of samples that was analyzed included at least one sample of USGS G-2 standard and Standard Pacific Sediment (see Owen and Ruhlin, this volume) to evaluate precision, variations between and within sample batches, and USGS GSP-1 and in-house synthetic standards as calibration standards. These results are summarized in Table 1 .

\section{RESULTS AND DISCUSSION}

A summary of elemental concentrations and mass accumulation rates (MARs) for each sample is presented in Tables 2 and 3. Also included are sample ages calculated from biostratigraphy and core depth (Site 598 chapter, this volume) and the calculated distance between the point at which the sediments in the samples were deposited and the position of the paleorise crest (see Rea, this volume). Site 598 is presently about $1150 \mathrm{~km}$ from the rise crest. Various geochemical anomalies indicative of hydrothermal plumes suggest that the plumes are transported well beyond this distance in this region of the South Pacific (Dymond, 1981; Lupton and Craig, 1981). Hence, we infer that Site 598 sediments reflect a continuous record of the deposition of hydrothermal precipitates.
Table 1. Comparison of INAA values for USGS-G2 standard with suggested values.

\begin{tabular}{crrrr}
\hline Element $^{\mathrm{a}}$ & $\begin{array}{c}\text { INAA } \\
\text { mean value }\end{array}$ & $\begin{array}{c}\text { Standard } \\
\text { deviation }\end{array}$ & $\begin{array}{c}\text { Precision } \\
(\%)\end{array}$ & $\begin{array}{c}\text { Suggested } \\
\text { value }\end{array}$ \\
\hline $\mathrm{Fe}$ & 1.88 & 0.02 & 0.90 & 1.88 \\
$\mathrm{La}$ & 93.52 & 1.64 & 1.75 & 96.00 \\
$\mathrm{Ce}$ & 165.01 & 23.71 & 14.37 & 150.00 \\
$\mathrm{Nd}$ & 50.73 & 7.56 & 14.90 & 60.00 \\
$\mathrm{Sm}$ & 7.75 & 0.10 & 1.29 & 7.30 \\
$\mathrm{Eu}$ & 1.54 & 0.12 & 7.79 & 1.50 \\
$\mathrm{~Tb}$ & 0.42 & 0.11 & 25.66 & 0.54 \\
$\mathrm{Yb}$ & 0.73 & 0.08 & 10.51 & 0.88 \\
$\mathrm{Lu}$ & 0.09 & 0.01 & 11.11 & 0.11 \\
\hline
\end{tabular}

Note: INAA values for USGS-G2 standard are based on three replicate analyses. USGS-G2 standard was not analyzed for $\mathrm{Mn}$; replicate analyses of Standard Pacific Sediment indicates that precision for this element was $1.6 \%$. Suggested values are from Flanagan (1973).

a INAA mean values, standard deviations, and suggested values for $\mathrm{Fe}$ are in \%; for other elements these values are in ppm.

\section{Compositional Integrity of the Hydrothermal Component}

An accurate assessment of the influence of seawater scavenging on the REE geochemistry of the sediments at Site 598 is directly related to the number and complexity of other possible causes of REE compositional variation. If the sediments are derived from multiple sources, for example, or if they have undergone extensive compositional changes as a result of diagenesis, our ability to make an unambiguous interpretation would be correspondingly diminished. Several lines of evidence suggest that these types of problems are minimal in the present study.

On the basis of compositional similarities that exist among hydrothermal sediments through space and time in this part of the Pacific Ocean, Leinen (1981) concluded that there has been remarkably little variation in the initial composition of the hydrothermal fluid over the past 30 to 60 m.y. Moreover, a major consideration in the positioning of Site 598 (as well as other sites of Leg 92) was prior knowledge (Leinen, 1981) that the sediments there were likely to be lithologically simple and unaffected by significant diagenetic alteration. This was done to ensure minimal dilution of the hydrothermal component by terrigenous and biogenic materials, and to avoid the possibility of remobilization of trace elements by reducing conditions associated with organic carbon diagenesis. On the basis of shipboard examination of Site 598 sediments, it appears that this sampling strategy was successful: the sediments recovered reflect a highly oxidized system consisting of two major components, biogenic carbonates and hydrothermal precipitates, with only trace amounts of material from other sources and no evidence of organic diagenesis.

The most compelling argument that the composition of the hydrothermal component of Site 598 sediments has remained constant is obtained from a quantitative comparison of the down-core versus modern-day geochemistry of the hydrothermal component. Dymond (1981) found that the composition of the hydrothermal component of surficial sediments in the general region 
Table 2. Summary of elemental concentration data for Site 598.

\begin{tabular}{|c|c|c|c|c|c|c|c|c|c|c|c|}
\hline $\begin{array}{c}\text { Core-Section } \\
\text { (interval in cm) }\end{array}$ & $\begin{array}{l}\text { Age } \\
\text { (m.y.) }\end{array}$ & $\begin{array}{l}\text { Distance } \\
\text { from } \\
\text { paleorise } \\
\text { crest }(\mathrm{km})\end{array}$ & $\begin{array}{l}\mathrm{Fe} \\
(\%)\end{array}$ & $\underset{(\mathrm{ppm})}{\mathrm{La}}$ & $\begin{array}{c}\mathrm{Ce} \\
(\mathrm{ppm})\end{array}$ & $\begin{array}{c}\mathrm{Nd} \\
(\mathrm{ppm})\end{array}$ & $\underset{(\mathrm{ppm})}{\mathrm{Sm}}$ & $\begin{array}{c}\text { Eu } \\
(\mathrm{ppm})\end{array}$ & $\begin{array}{c}\mathrm{Tb} \\
(\mathrm{ppm})\end{array}$ & $\begin{array}{c}\mathrm{Yb} \\
(\mathrm{ppm})\end{array}$ & $\underset{(\mathrm{ppm})}{\mathrm{Lu}}$ \\
\hline $1-1,8-10$ & 0.17 & 1139.0 & 1.59 & 27.30 & 11.08 & 21.90 & 6.01 & 1.61 & 1.20 & 3.72 & 0.81 \\
\hline $1-1,46-48$ & 0.47 & 1085.0 & 6.87 & 124.48 & 47.72 & 68.53 & 26.10 & 6.61 & 4.22 & 15.09 & 3.96 \\
\hline $1-1,68-70$ & 0.69 & 1055.0 & 8.44 & 141.38 & 55.06 & 123.53 & 29.77 & 7.53 & 5.44 & 17.54 & 3.92 \\
\hline $1-2,6-8$ & 1.57 & 970.0 & 3.76 & 52.69 & 16.40 & 38.73 & 10.84 & 2.68 & 1.84 & 6.11 & 1.50 \\
\hline $1-2,88-90$ & 2.39 & 912.0 & 13.69 & 188.83 & 42.09 & 159.19 & 34.00 & 9.21 & 6.95 & 21.86 & 4.73 \\
\hline $1-2,96-98$ & 2.47 & 904.0 & 13.36 & 176.55 & 39.66 & 116.02 & 32.74 & 8.44 & 6.13 & 19.88 & 4.99 \\
\hline $1-3,46-48$ & 3.47 & 832.0 & 6.42 & 83.32 & 17.99 & 42.80 & 14.39 & 3.70 & 2.43 & 8.90 & 2.24 \\
\hline $1-3,88-90$ & 3.89 & 802.0 & 4.29 & 52.47 & 9.37 & 42.66 & 8.72 & 2.39 & 1.49 & 5.68 & 1.19 \\
\hline $1-4,6-8$ & 4.57 & 742.0 & 1.40 & 17.92 & 3.75 & - & 2.61 & 0.67 & 0.35 & 1.83 & 0.47 \\
\hline $1-4,48-50$ & 4.99 & 710.0 & 9.53 & 97.97 & 19.40 & 47.95 & 14.63 & 3.99 & 3.03 & 10.25 & 2.30 \\
\hline $1-4,96-98$ & 5.47 & 675.0 & 1.85 & 19.13 & 3.32 & - & 2.75 & 0.71 & 0.40 & 1.95 & 0.45 \\
\hline $2-1,46-48$ & 6.67 & 596.0 & 1.30 & 10.78 & 2.02 & - & 1.72 & 0.44 & 0.27 & 1.19 & 0.28 \\
\hline $2-1,88-90$ & 7.07 & 574.0 & 1.44 & 9.86 & - & - & 1.90 & 0.53 & 0.29 & 1.23 & 0.26 \\
\hline $2-2,6-8$ & 7.44 & 540.0 & 2.13 & 14.01 & 2.79 & - & 2.27 & 0.58 & 0.46 & 1.51 & 0.32 \\
\hline $2-2,58-60$ & 7.72 & 513.0 & 2.65 & 14.94 & 2.05 & - & 2.47 & 0.63 & 0.40 & 1.67 & 0.33 \\
\hline $2-2,96-98$ & 7.92 & 500.0 & 2.60 & 15.82 & 3.20 & - & 2.53 & 0.68 & 0.44 & 1.66 & 0.39 \\
\hline $2-3,46-48$ & 8.32 & 474.0 & 2.57 & 15.51 & 3.58 & - & 2.48 & 0.63 & 0.40 & 1.65 & 0.36 \\
\hline $2-4,6-8$ & 8.67 & 453.0 & 4.52 & 22.74 & 5.52 & - & 3.66 & 0.94 & 0.50 & 2.32 & 0.56 \\
\hline $2-4,28-30$ & 8.74 & 450.0 & 4.79 & 22.33 & 4.06 & 17.69 & 3.77 & 1.05 & 0.67 & 2.38 & 0.52 \\
\hline $2-4,48-50$ & 8.81 & 444.0 & 4.08 & 20.14 & 4.85 & - & 3.29 & 0.88 & 0.78 & 2.08 & 0.48 \\
\hline $2-4,96-98$ & 8.96 & 436.0 & 5.13 & 23.64 & 5.56 & - & 3.73 & 0.99 & 0.57 & 2.32 & 0.56 \\
\hline $2-5,46-48$ & 9.31 & 414.0 & 5.99 & 27.62 & 5.43 & 19.18 & 4.05 & 1.13 & 0.62 & 2.45 & 0.65 \\
\hline $2-5,88-90$ & 9.49 & 404.0 & 6.68 & 28.17 & 7.14 & 16.52 & 4.56 & 1.26 & 0.79 & 2.82 & 0.60 \\
\hline $2-6,6-8$ & 9.77 & 385.0 & 5.83 & 24.84 & 6.03 & 21.09 & 4.02 & 1.08 & 0.60 & 2.41 & 0.57 \\
\hline $2-6,96-98$ & 10.15 & 363.0 & 6.89 & 29.09 & 8.10 & - & 4.73 & 1.24 & 1.03 & 2.70 & 0.66 \\
\hline $3-1,58-60$ & 11.21 & 298.0 & 9.21 & 32.50 & 3.68 & 6.55 & 5.18 & 1.41 & 0.88 & 3.25 & 0.67 \\
\hline $3-2,6-8$ & 12.06 & 244.0 & 5.22 & 18.29 & 4.22 & - & 2.79 & 0.73 & 0.40 & 1.76 & 0.46 \\
\hline $3-3,18-20$ & 12.34 & 227.0 & 4.98 & 18.17 & 2.71 & 11.56 & 2.92 & 0.82 & 0.40 & 1.87 & 0.38 \\
\hline $3-4,6-8$ & 12.58 & 212.0 & 4.04 & 14.32 & 2.30 & - & 2.07 & 0.53 & 0.39 & 1.29 & 0.31 \\
\hline $3-5,18-20$ & 12.86 & 194.0 & 3.68 & 11.88 & - & - & 1.91 & 0.52 & 0.36 & 1.32 & 0.26 \\
\hline $3-6,8-10$ & 13.11 & 178.0 & 4.87 & 13.99 & 1.09 & 12.07 & 2.37 & 0.65 & 0.43 & 1.42 & 0.31 \\
\hline $3-6,96-98$ & 13.26 & 170.0 & 6.16 & 23.62 & 4.59 & - & 3.48 & 0.91 & 0.43 & 2.04 & 0.49 \\
\hline $4-1,68-70$ & 13.57 & 152.0 & 9.95 & 32.47 & 4.12 & 13.63 & 4.82 & 1.25 & 0.67 & 2.88 & 0.65 \\
\hline $4-2,6-8$ & 13.73 & 140.0 & 4.94 & 18.31 & 2.67 & - & 2.58 & 0.71 & 0.36 & 1.52 & 0.37 \\
\hline $4-3,8-10$ & 13.99 & 122.0 & 6.54 & 24.56 & 1.71 & 6.13 & 3.73 & 1.02 & 0.59 & 2.03 & 0.44 \\
\hline $4-3,46-48$ & 14.06 & 120.0 & 6.53 & 21.20 & - & - & 3.17 & 0.83 & 0.43 & 1.81 & 0.42 \\
\hline $4-4,6-8$ & 14.23 & 109.0 & 5.68 & 18.24 & 3.47 & - & 2.80 & 0.72 & 0.36 & 1.55 & 0.36 \\
\hline $4-4,96-98$ & 14.34 & 103.0 & 3.54 & 12.84 & 1.98 & - & 1.96 & 0.49 & 0.28 & 1.62 & 0.26 \\
\hline $4-5,46-48$ & 14.47 & 95.0 & 7.25 & 15.43 & - & - & 2.57 & 0.71 & 0.37 & 1.49 & 0.32 \\
\hline $4-6,19-21$ & 14.62 & 85.0 & 9.39 & 29.80 & 2.15 & 19.63 & 4.51 & 1.23 & 0.73 & 2.67 & 0.58 \\
\hline $5-1,46-48$ & 14.91 & 66.0 & 8.64 & 18.13 & - & - & 2.81 & 0.74 & 0.31 & 1.63 & 0.42 \\
\hline $5-1,129-131$ & 15.01 & 61.0 & 7.15 & 31.76 & 5.23 & 25.73 & 4.00 & 1.08 & 0.57 & 2.17 & 0.42 \\
\hline $5-2,96-98$ & 15.16 & 52.0 & 8.90 & 29.99 & - & 18.91 & 4.71 & 1.25 & 0.58 & 2.58 & 0.64 \\
\hline $5-2,138-140$ & 15.21 & 48.0 & 7.97 & 26.67 & 2.60 & 17.80 & 4.25 & 1.12 & 0.68 & 2.27 & 0.45 \\
\hline $5-3,108-110$ & 15.36 & 40.0 & 10.25 & 30.23 & 4.51 & 23.38 & 5.03 & 1.31 & 0.83 & 2.61 & 0.57 \\
\hline $5-4,6-8$ & 15.42 & 36.0 & 8.72 & 32.90 & 6.03 & 20.86 & 4.86 & 1.32 & 0.72 & 2.67 & 0.60 \\
\hline $5-4,108-110$ & 15.54 & 28.0 & 12.14 & 35.65 & 4.78 & 24.10 & 5.68 & 1.49 & 0.81 & 2.98 & 0.61 \\
\hline $5-5,46-48$ & 15.65 & 20.0 & 8.52 & 28.53 & 6.92 & - & 4.16 & 1.10 & 0.54 & 2.17 & 0.53 \\
\hline $5-5,128-130$ & 15.75 & 16.0 & 13.54 & 16.33 & - & 15.36 & 3.70 & 0.97 & 0.52 & 1.70 & 0.40 \\
\hline $5-6,58-60$ & 15.85 & 9.0 & 8.07 & 18.40 & 1.04 & 14.90 & 3.19 & 0.84 & 0.42 & 1.62 & 0.34 \\
\hline Seawater $^{\mathrm{a}} \times 10^{6}$ & & & & 3.40 & 1.20 & 2.80 & 0.45 & 0.13 & 0.14 & 0.82 & 0.15 \\
\hline
\end{tabular}

Note: Dashes indicate concentration below detection limits; concentration data are not corrected for carbonate content.

a Seawater values from Høgdahl et al. (1968).

of the South Pacific, which includes Site 598, is remarkably constant. It is so constant, in fact, that it can be readily identified and distinguished from sedimentary material from other sources on the basis of highly characteristic ratios among various elements that are representative of a pure end-member hydrothermal component. If the composition of the hydrothermal component in Site 598 sediments has remained constant over space and time, then the elemental ratios determined for our down-core samples should be reasonably close to those reported for surficial sediments. On the other hand, if the original composition of the hydrothermal source has changed or if there has been diagenetic remobilization and segregation of trace elements, or both, then these effects should be manifested by significant differences in a comparison of elemental ratios.

Dymond (1981) determined the concentration of $\mathrm{Fe}$ in pure hydrothermal material to be $34.8 \%$ and calculated all elemental ratios relative to this element. Consequently, we calculated a linear regression for certain elements versus $\mathrm{Fe}$ in our 50 down-core samples, and then substituted this $\mathrm{Fe}$ value into each equation to obtain predicted end-member hydrothermal concentrations for each element. Ratios between each of these end-member concentrations and Fe were then calculated. A comparison of our values with those reported by Dymond (1981) is shown in Table 4. In general, there is excellent agreement between these values. The close agreement between 
Table 3. Summary of mass accumulation rate (MAR) data for Site 598.

\begin{tabular}{|c|c|c|c|c|c|c|c|c|c|}
\hline \multirow{2}{*}{$\begin{array}{l}\text { Core-Section } \\
\text { (interval in } \mathrm{cm} \text { ) }\end{array}$} & \multicolumn{9}{|c|}{ MARs } \\
\hline & $\mathrm{Fe}$ & $\mathrm{La}$ & $\mathrm{Ce}$ & $\mathrm{Nd}$ & $\mathrm{Sm}$ & Eu & $\mathrm{Tb}$ & $\mathrm{Yb}$ & Lu \\
\hline $1-1,8-10$ & 0.51 & 0.87 & 0.35 & 0.70 & 0.19 & 0.05 & 0.04 & 0.12 & 0.03 \\
\hline $1-1,46-48$ & 2.18 & 3.95 & 1.51 & 2.18 & 0.83 & 0.21 & 0.13 & 0.48 & 0.13 \\
\hline $1-1,68-70$ & 2.68 & 4.49 & 1.75 & 3.92 & 0.95 & 0.24 & 0.17 & 0.56 & 0.12 \\
\hline $1-2,6-8$ & 2.64 & 3.70 & 1.15 & 2.72 & 0.76 & 0.19 & 0.13 & 0.43 & 0.11 \\
\hline $1-2,88-90$ & 9.60 & 13.20 & 2.95 & 11.20 & 2.40 & 0.65 & 0.49 & 1.53 & 0.33 \\
\hline $1-2,96-98$ & 9.37 & 12.40 & 2.78 & 8.14 & 2.30 & 0.59 & 0.43 & 1.39 & 0.35 \\
\hline $1-3,46-48$ & 4.50 & 5.84 & 1.26 & 3.00 & 1.01 & 0.26 & 0.17 & 0.62 & 0.16 \\
\hline $1-3,88-90$ & 3.01 & 3.68 & 0.66 & 2.99 & 0.61 & 0.17 & 0.11 & 0.40 & 0.08 \\
\hline $1-4,6-8$ & 0.98 & 1.26 & 0.26 & - & 0.18 & 0.05 & 0.03 & 0.13 & 0.03 \\
\hline $1-4,48-50$ & 11.10 & 8.57 & 1.70 & 5.57 & 1.28 & 0.35 & 0.35 & 1.19 & 0.20 \\
\hline $1-4,96-98$ & 2.15 & 1.67 & 0.29 & - & 0.24 & 0.06 & 0.05 & 0.23 & 0.04 \\
\hline $2-1,46-48$ & 2.06 & 1.71 & 0.53 & - & 0.44 & 0.11 & 0.04 & 0.19 & 0.07 \\
\hline $2-1,88-90$ & 2.28 & 1.56 & - & - & 0.30 & 0.08 & 0.05 & 0.20 & 0.04 \\
\hline $2-2,6-8$ & 3.38 & 2.22 & 0.44 & - & 0.36 & 0.09 & 0.07 & 0.24 & 0.05 \\
\hline $2-2,58-60$ & 4.20 & 2.37 & 0.33 & - & 0.39 & 0.10 & 0.06 & 0.27 & 0.05 \\
\hline $2-2,96-98$ & 4.13 & 2.51 & 0.51 & - & 0.40 & 0.11 & 0.07 & 0.26 & 0.06 \\
\hline $2-3,46-48$ & 6.76 & 4.08 & 0.94 & - & 0.65 & 0.17 & 0.11 & 0.43 & 0.10 \\
\hline $2-4,6-8$ & 11.89 & 5.98 & 0.15 & - & 0.96 & 0.25 & 0.13 & 0.61 & 0.15 \\
\hline $2-4,28-30$ & 12.60 & 5.87 & 1.07 & 4.65 & 1.00 & 0.28 & 0.18 & 0.63 & 0.14 \\
\hline $2-4,48-50$ & 10.70 & 5.29 & 1.27 & - & 0.86 & 0.23 & 0.21 & 0.55 & 0.13 \\
\hline $2-4,96-98$ & 13.50 & 6.21 & 1.46 & - & 0.98 & 0.26 & 0.15 & 0.61 & 0.15 \\
\hline $2-5,46-48$ & 12.70 & 5.87 & 1.15 & 4.07 & 0.86 & 0.24 & 0.13 & 0.52 & 0.14 \\
\hline $2-5,88-90$ & 14.20 & 5.98 & 1.52 & 3.51 & 0.97 & 0.27 & 0.17 & 0.60 & 0.13 \\
\hline $2-6,6-8$ & 12.40 & 5.28 & 1.28 & 4.48 & 0.85 & 0.23 & 0.13 & 0.51 & 0.12 \\
\hline $2-6,96-98$ & 14.60 & 6.18 & 1.72 & - & 1.01 & 0.26 & 0.22 & 0.57 & 0.14 \\
\hline $3-1,58-60$ & 5.92 & 2.09 & 0.24 & 0.42 & 0.33 & 0.09 & 0.06 & 0.21 & 0.04 \\
\hline $3-2,6-8$ & 22.00 & 7.71 & 1.78 & - & 1.18 & 0.31 & 0.17 & 0.74 & 0.19 \\
\hline $3-3,18-20$ & 21.00 & 7.66 & 1.14 & 4.88 & 1.23 & 0.35 & 0.17 & 0.79 & 0.16 \\
\hline $3-4,6-8$ & 17.00 & 6.04 & 0.97 & - & 0.87 & 0.22 & 0.17 & 0.54 & 0.13 \\
\hline $3-5,18-20$ & 15.50 & 5.01 & - & - & 0.81 & 0.20 & 0.15 & 0.56 & 0.11 \\
\hline $3-6,8-10$ & 20.50 & 5.90 & 0.46 & 50.90 & 1.00 & 0.27 & 0.18 & 0.60 & 0.13 \\
\hline $3-6,96-98$ & 26.00 & 9.96 & 1.94 & - & 1.47 & 0.38 & 0.18 & 0.86 & 0.21 \\
\hline $4-1,68-70$ & 42.00 & 13.70 & 1.74 & 57.50 & 2.03 & 0.53 & 0.28 & 1.21 & 0.27 \\
\hline $4-2,6-8$ & 20.80 & 7.72 & 1.13 & - & 1.09 & 0.30 & 0.15 & 0.64 & 0.16 \\
\hline $4-3,8-10$ & 27.60 & 10.40 & 0.72 & 25.90 & 1.57 & 0.43 & 0.25 & 0.86 & 0.19 \\
\hline $4-3,46-48$ & 27.50 & 8.94 & - & - & 1.34 & 0.35 & 0.18 & 0.76 & 0.18 \\
\hline $4-4,6-8$ & 30.80 & 9.88 & 1.88 & - & 1.52 & 0.39 & 0.20 & 0.84 & 0.20 \\
\hline $4-4,96-98$ & 19.20 & 6.96 & 1.07 & - & 1.06 & 0.27 & 0.15 & 0.88 & 0.14 \\
\hline $4-5,46-48$ & 39.30 & 8.36 & - & - & 1.39 & 0.39 & 0.20 & 0.81 & 0.17 \\
\hline $4-6,19-21$ & 50.90 & 16.10 & 1.17 & 10.60 & 2.44 & 0.67 & 0.40 & 1.45 & 0.31 \\
\hline $5-1,46-48$ & 46.80 & 9.82 & - & - & 1.52 & 0.40 & 0.17 & 0.88 & 0.23 \\
\hline $5-1,129-131$ & 38.70 & 17.20 & 2.83 & 13.90 & 2.17 & 0.59 & 0.31 & 1.18 & 0.23 \\
\hline $5-2,96-98$ & 48.20 & 16.20 & - & 10.24 & 2.55 & 0.68 & 0.31 & 1.40 & 0.35 \\
\hline $5-2,138-140$ & 43.20 & 14.50 & 1.41 & 9.64 & 2.30 & 0.61 & 0.37 & 1.23 & 0.24 \\
\hline $5-3,108-110$ & 55.50 & 16.40 & 2.44 & 16.40 & 2.73 & 0.71 & 0.45 & 1.41 & 0.31 \\
\hline $5-4,6-8$ & 47.20 & 17.80 & 3.27 & 11.30 & 2.63 & 0.72 & 0.39 & 1.45 & 0.33 \\
\hline $5-4,108-110$ & 65.80 & 19.30 & 2.59 & 19.30 & 3.08 & 0.81 & 0.44 & 1.61 & 0.33 \\
\hline $5-5,46-48$ & 46.16 & 15.50 & 3.75 & - & 2.25 & 0.60 & 0.29 & 1.18 & 0.29 \\
\hline $5-5,128-130$ & 73.35 & 8.85 & - & 8.32 & 2.00 & 0.53 & 0.28 & 0.92 & 0.22 \\
\hline $5-6,58-60$ & 43.72 & 9.97 & 0.56 & 8.07 & 1.73 & 0.46 & 0.23 & 0.88 & 0.18 \\
\hline
\end{tabular}

Note: Mass accumulation rates for Fe are expressed as $\left[\left(\mathrm{mg} / \mathrm{cm}^{2}\right) / 1000 \mathrm{yr}\right]$ and for REE as $\left[\left(\mu \mathrm{g} / \mathrm{cm}^{2}\right) / 1000 \mathrm{yr}\right.$.]; calculated using Hole 598 sediment data. Dashes indicate concentration was below detection limit; thus, MAR could not be calculated.

Table 4. Comparison of elemental ratios for pure hydrothermal material in Site 598 sediment with South Pacific surficial sediment.

\begin{tabular}{ccc}
\hline Ratio & $\begin{array}{l}\text { Site 598 } \\
\text { sediment }\end{array}$ & $\begin{array}{c}\text { South Pacific } \\
\text { surficial sediment }\end{array}$ \\
\hline $\mathrm{Mn} / \mathrm{Fe}$ & 0.2799 & 0.2900 \\
$\mathrm{Zn} / \mathrm{Fe}$ & 0.0017 & 0.0019 \\
$\mathrm{Ba} / \mathrm{Fe}$ & 0.0049 & 0.0050 \\
$\mathrm{Ni} / \mathrm{Fe}$ & 0.0221 & 0.0009 \\
\hline
\end{tabular}

${ }^{a}$ From Dymond (1981).

the $\mathrm{Mn} / \mathrm{Fe}$ ratios is particularly encouraging, because the diagenetic behavior of these two elements is well understood (Krauskopf, 1957; Lynn and Bonatti, 1965) and because we regard this ratio as the most sensitive indicator of diagenetic remobilization. Dymond (1981) found a relatively high error associated with the $\mathrm{Ni} / \mathrm{Fe}$ ratio determined in his study and suggested that this may re- sult from a breakdown in the constant composition assumption for these elements. This factor could account for the rather poor agreement between the two $\mathrm{Ni} / \mathrm{Fe}$ ratios shown in Table 4.

On the basis of the considerations discussed above, we conclude the following: (1) the original composition of the hydrothermal component in Site 598 sediments has not varied with time or as a result of diagenetic alteration; (2) the influence of trace amounts of terrigenous, hydrogenous, on noncarbonate biogenic material in our samples is minimal; and therefore, (3) it is reasonable to interpret variations in the REE geochemistry of this component as being primarily caused by the interaction of hydrothermal precipitates and seawater.

\section{REE Geochemistry}

The REE pattern of seawater has two prominent features: (1) a strong negative $\mathrm{Ce}$ anomaly that occurs because this element can be oxidized to the +4 oxidation state, which has a relatively high affinity for solid phases; and (2) a pronounced enrichment of the heavy REEs (HREEs) relative to the light REEs (LREEs) resulting from the relatively greater stability of HREE complexes in seawater. Certain ratios among the REE that are considered characteristic of these features serve as a measure of how closely the REE pattern of any given marine phase approaches that of seawater. For example, Figure 1 clearly shows the Ce anomaly of Site 598 sediments approaching that of seawater with increasing distance from the rise crest. (The $\mathrm{Ce}$ anomaly equals $\log [\mathrm{Ce} /(2 / 3 \mathrm{La}+$ $1 / 3 \mathrm{Nd})]$, and it is an index of the relative availability of Ce; Elderfield and Greaves, 1981.) Similarly, significant ( 0.05 level) correlations between the paleodistance and both the $\mathrm{La} / \mathrm{Sm}$ ratio (a measure of LREE behavior) and the $\mathrm{Yb} / \mathrm{Sm}$ ratio (a measure of HREE behavior) indicate that the REE patterns of Site 598 sediments become more like that of seawater with increasing distance from the rise crest. Interelement correlations among the REEs are all strongly positive, which is indicative of the coherency of chemical behavior of these elements in the marine environment (Piper, 1974a,b; Elderfield and Greaves, 1982).

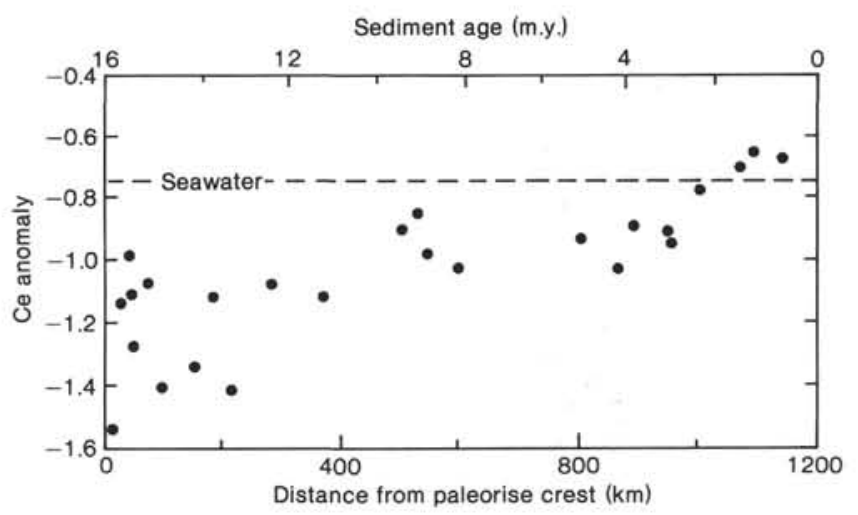

Figure 1. Plot of the Ce anomaly versus paleodistance, Site 598 samples. Dashed line indicates seawater Ce anomaly value (data from Høgdahl et al., 1968). 
Statistically significant $(0.05$ level) co-variant trends between several of the variables reported in Tables 2 and 3 support the argument that REEs are scavenged from seawater by hydrothermal precipitates. As shown in Figure 2, the MARs of $\mathrm{Fe}$ and the REEs generally decrease with increasing paleodistance from the rise crest, whereas the concentration of REEs in Site 598 sediments in-
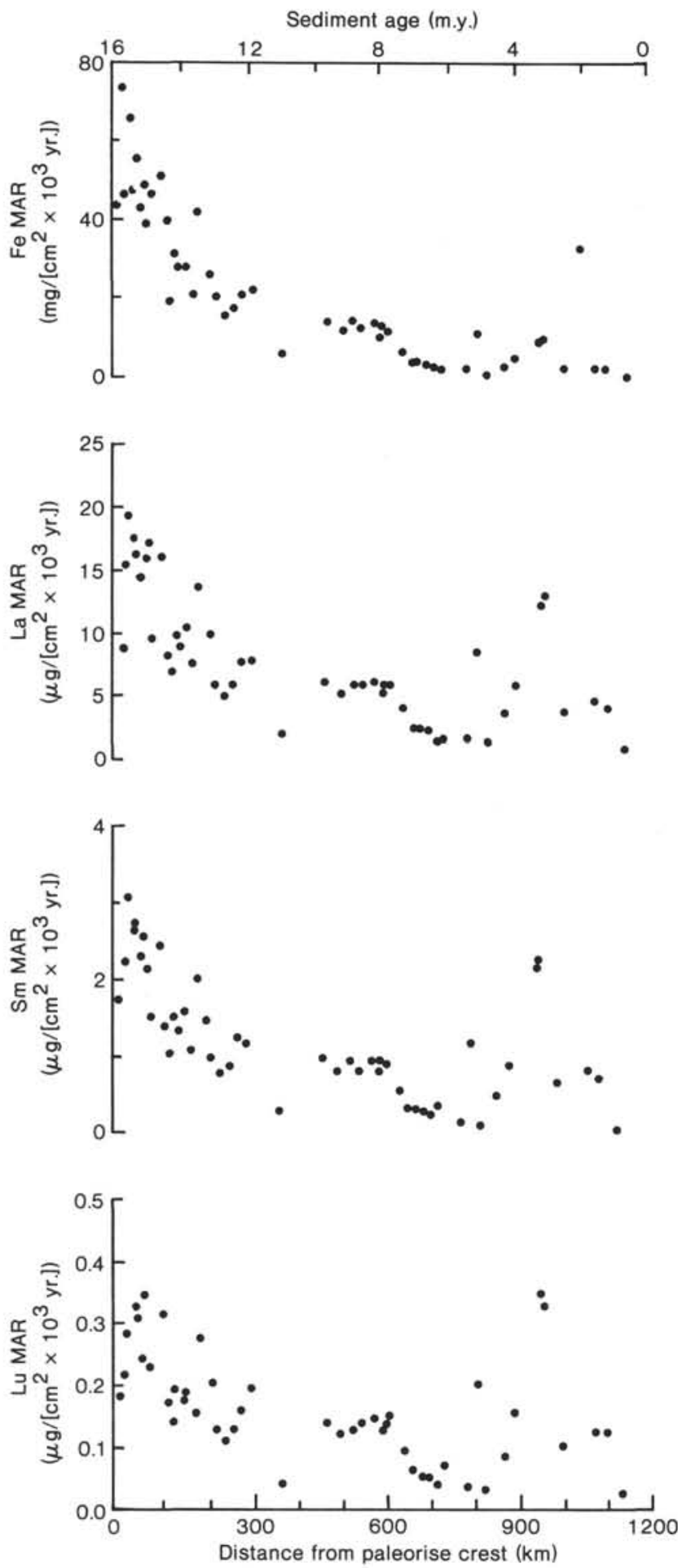

Figure 2. Mass accumulation rates for $\mathrm{Fe}$ and some representative REEs in sediments from Site 598, plotted versus paleodistance. creases with increasing distance from the rise crest. The spike in each of these plots at 3 to $5 \mathrm{Ma}$ is believed to be the result of a period of markedly increased hydrothermal activity relative to present levels (see Lyle et al., this volume). Individual REE concentrations (except $\mathrm{Ce}$ ) are positively correlated with $\mathrm{Fe}$ concentration, but negatively correlated with the Fe MAR. Shale-normalized REE abundance patterns for a few representative samples from Site 598 are shown in Figure 3; the abundance patterns for all samples in this study fall within the range defined by the two extremes shown in this plot. The REE patterns of all samples are very similar to that of seawater (Fig. 3) and differ only in absolute REE abundance. Thus, it is again observed that sediments deposited near the rise crest have the lowest REE abundances, and that absolute REE abundances increase with increasing paleodistance from the rise crest.

The inclusion of a REE pattern for biogenous carbonates (based on foraminifers) (Elderfield et al., 1981) in Figure 3 requires further elaboration. As noted above, Site 598 sediments contain only two major components: biogenous carbonates and hydrothermal material. Since the Fe MAR decreases away from the rise crest, the input of biogenic material becomes relatively more important. Thus, it is theoretically possible that the observed increase in REE abundance is due simply to relatively larger inputs of the biogenic component (ignoring, for the moment, any dissolution effects). If this were true, then absolute REE abundances should approach that of a pure biogenous carbonate end-member with increasing paleodistance. In fact, the observed trend is just the opposite: absolute REE abundances in biogenous carbonates are quite low in comparison to Site 598 sedi-

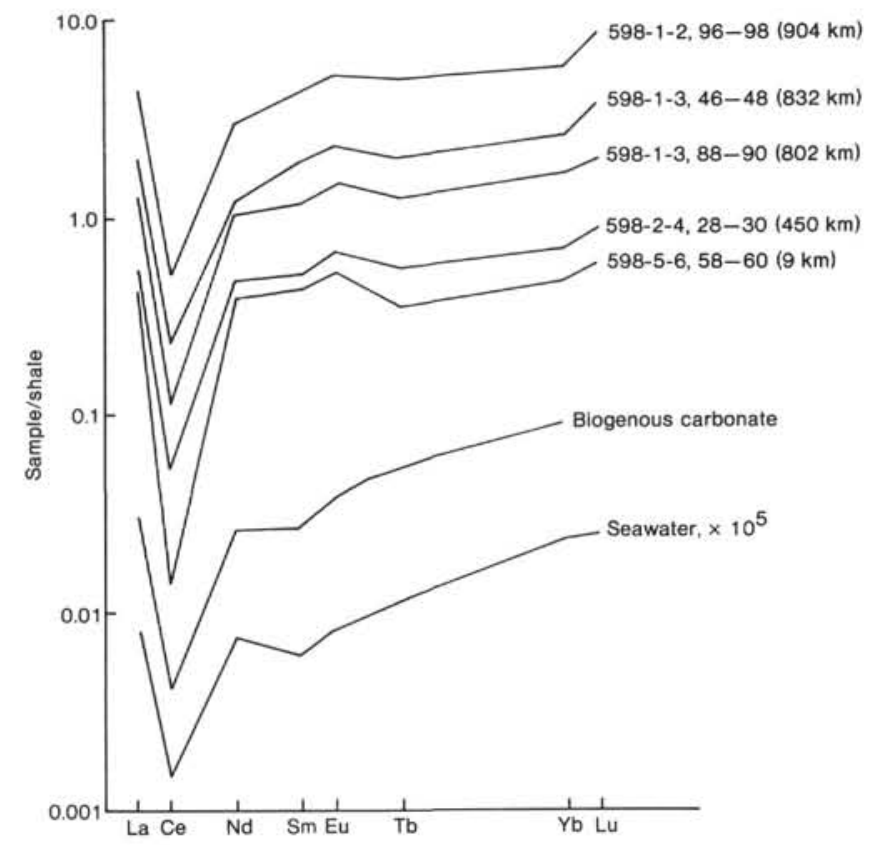

Figure 3. Shale-normalized REE patterns for representative Site 598 samples, biogenous carbonate (Elderfield et al., 1981), and seawater $\left(\times 10^{5}\right)$ (Høgdahl et al., 1968). Values in parentheses indicate sample distance from the paleorise crest. (Shale data from Haskin et al., 1966.) 
ments, and the trend toward increasing REE abundances with increasing paleodistance is actually moving away from a biogenic carbonate end-member. (We acknowledge that it would have been better to make this comparison using a REE abundance pattern characteristic of coccoliths rather than foraminifers for the biogenic carbonate end-member, because the carbonate component of Site 598 sediments consists mainly of coccolith ooze. Unfortunately, we were unable to locate a characteristic REE pattern for coccoliths in the literature. We do suspect, however, that there is probably very little difference between the REE abundance patterns of these biogenic carbonate groups.)

The most conclusive evidence in support of a seawater scavenging mechanism is summarized in Figure 4. Here we observe that the absolute abundance of REEs per unit of $\mathrm{Fe}$ increases significantly with increasing paleodistance from the rise crest and exposure to seawater. The observed increase is gradual in sediments deposited above the paleolysocline and quite pronounced for sediments deposited below it. (The position of the paleolysocline shown in Fig. 4 is taken from Leinen and Rea, this volume.) Apparently scavenging of REEs by hydrothermal precipitates occurs both during transport and after deposition. The onset of rapid carbonate dissolution in sediments deposited below the lysocline minimizes burial rates and prolongs the exposure of the hydrothermal residue in these sediments to seawater. This permits the scavenging process to continue for a relatively longer time period than that experienced by hydrothermal materials deposited above the lysocline.

\section{SUMMARY AND CONCLUSIONS}

The sediments present at DSDP Site 598 represent a complete record of hydrothermal activity at the East Pacific Rise for the past $16 \mathrm{~m}$.y. Several aspects of these deposits permit an unambiguous interpretation of the

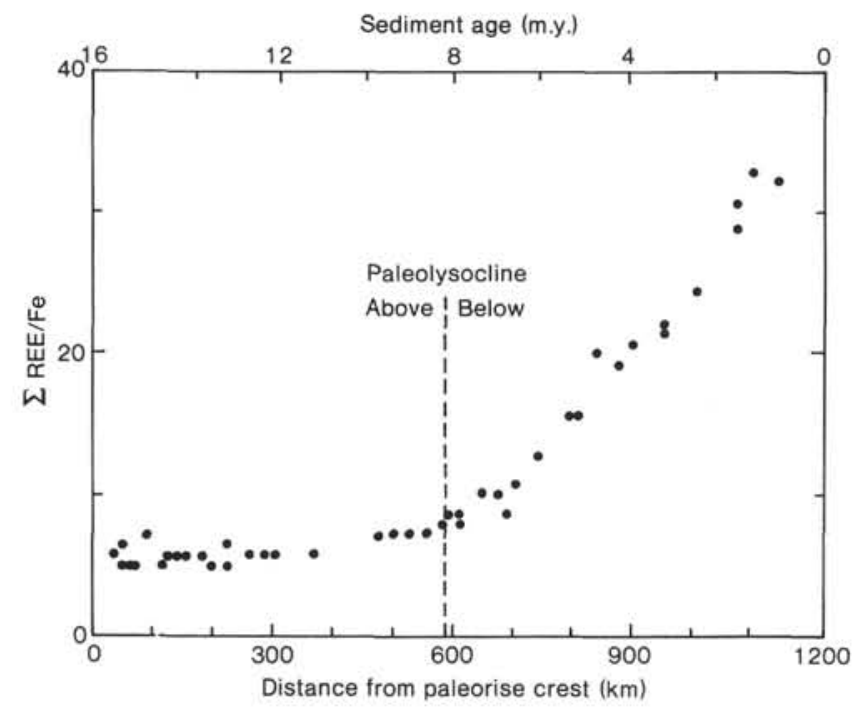

Figure 4. Plot of REE abundance (expressed as REE sum, excluding $\mathrm{Nd}$ because of limited data) per unit of $\mathrm{Fe}$ versus paleodistance for Site 598. Dashed line indicates approximate position at which sediments were deposited above and below the paleolysocline.
REE geochemistry of the hydrothermal component. Site 598 sediments contain only two major lithologic components: biogenic carbonates and hydrothermal precipitates. Key interelement ratios calculated for 50 downcore samples at Site 598 are in excellent agreement with similar ratios calculated by Dymond (1981) for pure hydrothermal surficial sediments. This agreement indicates that the bulk composition of the original hydrothermal component has remained essentially constant through space and time and has not been changed by contamination from trace components or by diagenetic alteration.

The various trends and interelement relationships discussed in this report are consistent with the following conceptual model for the acquisition of REEs by hydrothermal precipitates. Iron oxyhydroxides in the hydrothermal plume begin scavenging REEs from seawater as soon as the hydrothermal plume is ejected into bottom waters. Rapid burial (high MARs) of these precipitates near the rise crest minimizes their exposure to seawater and results in basal sediments that exhibit a REE pattern like that of seawater and relatively low REE abundances. The scavenging process continues as some of the precipitates disperse away from the injection point, resulting in relatively higher REE concentrations in precipitates that have been transported significant distances from the rise crest. The sharp increase observed in the $\mathrm{REE} / \mathrm{Fe}$ ratio that corresponds to the position of the paleolysocline indicates that REE scavenging continues as a postdepositional process and is especially evident in hydrothermal materials that have been maintained at or near the sediment-water interface for prolonged periods due to reworking by bottom currents, carbonate dissolution, or lower bulk sedimentation rates. Observed trends in various geochemical indices of REE behavior show that the REE patterns of distal hydrothermal materials are even more like those of seawater than their basal counterparts.

\section{ACKNOWLEDGMENTS}

We thank our colleagues on board Glomar Challenger during DSDP Leg 92 for their assistance in obtaining the samples and generating the shipboard data used in this study, and for making a long cruise a very pleasant one. M. Lyle, M. Kastner, D. K. Rea, and M. Leinen provided helpful comments and discussion concerning various aspects of this study. This research was supported in part by a Rackham Faculty Research Award and by the National Science Foundation under Grant No. OCE-8410034.

\section{REFERENCES}

Bender, M., Broecker, W., Gornitz, V., Middle, U., Kay, R., Sun, S. S., and Biscaye, P., 1971. Geochemistry of three cores from the East Pacific Rise. Earth Planet. Sci. Lett., 12:425-433.

Bowers, T. S., and Taylor, H. P., 1983. Chemical and isotopic mass transfer calculations pertaining to seafloor hydrothermal systems. Geol. Soc. Am. Abstr. Prog., 15:531.

Cronan, D. S., 1980. Underwater Minerals: New York (Academic Press).

Dams, R., and Robbins, V. A., 1970. Nondestructive Activation Analysis of Environmental Samples. Univ. Michigan Great Lakes Res. Div. Tech. Rept. 48.

Dymond, J., 1981. The geochemistry of Nazca Plate sediments: an evaluation of hydrothermal, biogenic detrital, and hydrogenous sources. Mem. Geol. Soc. Am., 154:133-173.

Dymond, J., Corliss, J. B., Heath, G. R., Field, C. W., Dasch, E. J., and Veeh, H. H., 1973. Origin of metalliferous sediments from the Pacific Ocean. Geol. Soc. Am. Bull., 84:3355-3372. 
Edmond, J. M., Corliss, J. B., and Gordon, L. I., 1979. Ridge crest hydrothermal metamorphism of the Galapagos Spreading Center and reverse weathering. In Talwani, M., et al. (Eds.), Deep Drilling Results in the Atlantic Ocean: Ocean Crust. Am. Geophys. Union, Maurice Ewing Ser., 2:383-390.

Edmond, J. M., Measures, C., Mangum, B., Grant, B., Sclater, F. K., Collier, R., Hudson, A., Gordon, L. I., and Corliss, J. B., 1979. On the formation of metal-rich deposits of ridge crests. Earth Planet. Sci. Lett., 46:19-30.

Elderfield, H., and Greaves, M. J., 1981. Negative cerium anomalies in the rare earth element patterns of oceanic ferromanganese nodules. Earth Planet. Sci. Lett., 55:163-170.

1982. The rare earth elements in seawater. Nature (London), 296:214-219.

Elderfield, H., Hawkesworth, C. J., Greaves, M. J., and Calvert, S. E., 1981. Rare earth element geochemistry of oceanic ferromanganese nodules and associated sediments. Geochim. Cosmochim. Acta, 45:513-528.

Flanagan, F. J., 1973. 1972 values for international geochemistry reference samples. Geochim. Cosmochim. Acta, 37:1189-1200.

Goldberg, E. D., Koide, M., Schmitt, R. A., and Smith, R. H., 1963. Rare earth element distributions in the marine environment. J. Geophys. Res., 68:4209-4217.

Gordon, C. E., Randle, K., Goles, G. D., Corliss, J. B., Beesen, M. H., and Oxley, S. S., 1968. Instrumental activation analysis of standard rocks with high resolution X-ray detectors. Geochim. Cosmochim. Acta, 32:364-396.

Haskin, L. A., Frey, F. A., Schmitt, R. A., and Smith, R. H., 1966. Meteoric, solar, and terrestrial rare-earth distributions. In Ahrens, L. H., et al. (Eds.), Physics and Chemistry of the Earth: New York (Pergamon), 7:167-322.

Høgdahl, O. T., Melson, S., and Bowen, V., 1968. Neutron activation analysis of lanthanide elements in seawater. Adv. Chem. Ser., 73: 308-325.
Klinkhammer, G., Elderfield, H., and Hudson, A., 1983. Rare earth elements in seawater near hydrothermal vents. Nature (London), 305:185-188.

Krauskopf, K. B., 1957. Separation of manganese from iron in sedimentary processes. Geochim. Cosmochim. Acta, 12:61-84.

Leinen, M., 1981. Metal-rich basal sediments from northeastern Pacific Deep Sea Drilling Project sites. In Yeats, R. S., Haq, B. U., et al., Init. Repts. DSDP, 63: Washington (U.S. Govt. Printing Office), 667-676.

Lupton, J. E., and Craig H., 1981. A major helium-3 source at $15^{\circ} \mathrm{S}$ on the East Pacific Rise. Science (Washington, D.C.), 214:13-18.

Lyle, M., 1981. The formation and growth of ferromanganese oxides on the Nazca Plate. Mem. Geol. Soc. Am., 154:269-295.

Lynn, D. C., and Bonatti, E., 1965. Mobility of manganese in diagenesis of deep-sea sediments. Mar. Geol., 3:457-474.

Mottl, M. J., and Seyfried, W. E., 1980. Sub-seafloor hydrothermal systems: Rock- vs. seawater-dominated. In Rona, P. A., and Lowell, R. P. (Eds.), Seafloor Spreading Centers: Hydrothermal Systems: Stroudsburg, Pa. (Dowden, Hutchinson and Ross), pp. 66-82.

Owen, R. M., and Mackin, J. E., 1980. Authigenic associations between selected rare earth elements and trace metals in lacustrine sediments. Environ. Geol., 3:131-137.

Piper, D. Z., 1974a. Rare earth elements in the sedimentary cycle: a summary. Chem. Geol., 14:285-304.

1974b. Rare earth elements in ferromanganese nodules and other marine phases. Geochim. Cosmochim. Acta, 38:1007-1022.

Toth, J. R., 1980. Deposition of submarine crusts rich in manganese and iron. Geol. Soc. Am. Bull., 91:44-54.

Date of Initial Receipt: 2 July 1984

Date of Acceptance: 26 December 1984 